\title{
遊離部分脺に対する体外分割照射に関する実験的研究
}

\author{
北海道大学医学部第 2 外科教室（指導；田辺達三教授）
}

下 沢 英 二

\section{AN EXPERIMENTAL STUDY OF THE EFFECT OF DEVIDED IRRADIATION ON FUNCTION OF ISOLATED AND PARTIALIZED PANCREAS}

\section{Eiji SHIMOZAWA}

The Second Depertment of Surgery Hokkaido University, School of Medicine

膵部分切除後の残存膵に対する体外分割照射が内分泌機能に与兄る影響を知る目的で, 雑種成犬を 用いて $60 \%$ 膵切除を行い, 術後 3 週間を経た時点で臨床効果 $30 \mathrm{GY}$ おょび゙60GY 相当の体外分割照射 を行って切除単独群と比較検討した。 3 力月時の耐糖能は血糖消失率 $\mathrm{K}$ 值で切除単独群 $1.32 \pm 0.33$,

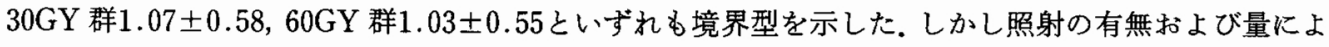
る影響はなかった。電顕像の計量組織学的検索では実験群で Insulin 顆粒の増加と同顆粒の Volume Density の増加（正常対照10.6, 切除単独群14.1，30GY 群26.9,60GY 群22.4) がみられた。 $60 \%$ 膵 切除・照射後 3 カ月時にみる限り，照射による内分泌機能への影響は認められなかった。耐糖能保時 の因子としてラ島機能の充進が考えられた.

索引用語 : 膵切除, 膵照射, ラ島機能, 膵内分泌機能, 計量組織学

\section{緒 言}

膵癌は腹腔内の諸臓器癌の中でもとりわけ治療成績 が不良であり，さまざまな治療対策がなされている。 放射線治療は早くより試みられているが, 多くは切除 不能膵癌に対するものである1). 最近, 膵切除後の集学 的治療として照射が用いられてきているが2), 照射後 の膵内分泌機能についての基礎的な報告は少ない，特 に切除・照射後の酎糖能について, 血糖や Insulin 分泌 を定量的に評価した報告はない.

術後照射が残存萃の耐糖能におよぼす影響を正確に 評価しておくことは, 膵切除量や照射量を考光る上で きわめて重要である。そのため本研究では雑種成犬を 用いて, 膵切除後に体外分割照射を行い, 膵内分泌機 能を検索した。

\section{I. 実験材料ならびに方法}

\section{1) 手術方法}

雑種成犬 $(8 \sim 12 \mathrm{Kg})$ を用い, イソゾール静脈麻酔・ 気管内插管調節呼吸下に, $60 \%(50 \% \sim 65 \%$, 平均 $57 \%$, 目測重量比）の膵切除を行い，残存膵を十二指腸とと

$<1988$ 年 1 月 13 日受理 > 別刷請求先：下沢 英二 干060 札幌市北区北14条西 5 丁目 北海道大学医学 部第 2 外科
もに挙上し, 前腹壁内正中部に作成したポケットに固 定した。主膵管は結禁切離し，副膵管にはチューブを 掩入し断端を腹腔内開放とした。照射の目標としてポ ケットの底部にヒューズを固定した（図 1)。

2) 照射方法

手術時に挿入したヒューズを TV 透視下に確かめ, 皮虚に照射野を記した。イソジール静脈麻酔下に実験 犬を照射台上に横臥させ, liniac 対向 2 門体外分割照 射を行った. Orton ${ }^{3) の ~ T i m e, ~ D o s e, ~ a n d ~ F r a c t i o n a-~}$ tion (以下 TDF) で換算 し， $6.0 \mathrm{GY} \times 4$ 回 $/ 12$ 日 $(\mathrm{TDF}=62$, 臨床効果 $30 \mathrm{GY}$ 相当), または $9.0 \mathrm{GY} \times 4$ 回 $/ 12$ 日（TDF $=116$, 臨床効果 $60 \mathrm{GY}$ 相当）の照射を 行った（図1).

\section{3）実験群の構成}

手術後 3 週時の耐糖能検査で手術に基づく異常のな いものを無作意に群分けした。処置しない正常全膵犬 を正常対照とし, 実験群は膵切除の及行った切除単独 群, 膵切除後臨床効果 $30 \mathrm{GY}$ 相当を照射した $30 \mathrm{GY}$ 群, 膵切除後臨床効果60GY 相当を照射した60GY 群の 3 群とした。

4) 内分泌学的検索

経静脈的ブドゥ糖負荷試験 (以下 IV.GTT)を行い, 
図 1 手術方法と照射方法

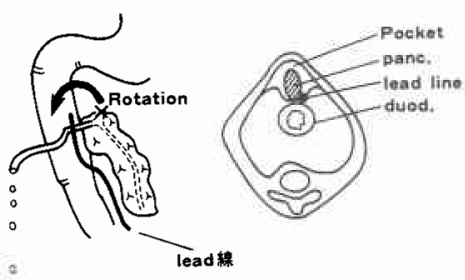

残脚前腹壁引上，固定.

滕液腹窑内開放

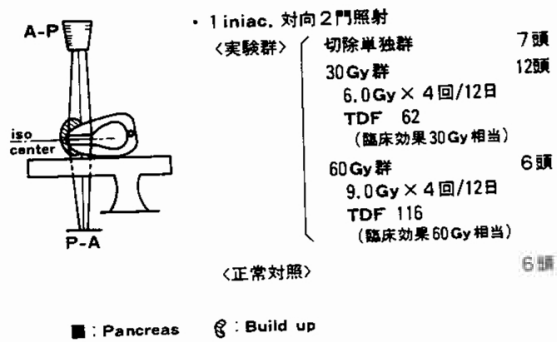

内分泌機能の指標とした.24時間の絶食の後, イソゾー ル静脈麻酔下に，前肢静脈より50\%グルコース（ブド ウ糖 $0.5 \mathrm{~g} / \mathrm{Kg}$ )を 1 分間かけて投与した。対側前肢静脈 より投与前，投与後 2 分・ 5 分・ 10 分・ 30 分・ 60 分に 採血し，血糖值执よび insulin（以下 IRI）值を測定し た. 血糖値は glucose oxydase 法, IRIは 2 抗体法に よった，検索は正常対照犬とともに，実験群では手術 後 3 週 (照射前値) と，手術または照射後 3 力月時に 施行した. 内分泌機能判定の指標として, 以下の各項 目について検討した。

1)：血糖曲線, IRI 曲線

口) : Insulinogenic Index (以下 I. I. )

ブドゥ糖負荷後 2 分の, 前值に対する IRI の堌加量を, 同様 2 分後の糖の増加量で除し, $\beta$ 細胞機能を推測し た4).

）：糖消失率（K 值）

血糖值を半詨数グラフにプロットし，血糖下降速度を 求め, 半減期 $(\mathrm{t} 1 / 2)$ を算出乙 $\mathrm{K}=(0.693 / \mathrm{t} 1 / 2) \times 100$ で表示した5).

$\Rightarrow$ ：IRI Peak 值, Peak Insulin Time

B 細胞の反応力と反応性を知るためそれぞれを求め た6).

木）：IRI 分泌量と Total Insulinogenic Index（以 下 T. I. I.)

残存膵の B 細胞機能の量的指標として IRI の総分泌
量 $\left(\Sigma I R I\left(0^{\prime}-60^{\prime}\right)\right)$ と, 増加量 $\left(\Sigma \Delta\right.$ IRI $\left.\left(0^{\prime} \sim 60^{\prime}\right)\right)$ を求めた。さささらにその IRI による糖処理能力を知る ため60分間の IRI 増加量を60分間の糖増加量で除した 值 T. I. I. $(\mu \mathrm{u} . \mathrm{dl} / \mathrm{ml} . \mathrm{mg})=\Sigma \Delta \mathrm{IRI}\left(0^{\prime} \sim 10^{\prime}\right) / \Sigma \Delta \mathrm{BS}$ ( $0^{\prime}$ 〜 60') を求めた ${ }^{7}$.

\section{5) 組織学的検索}

手術・照射後 3 力月時にIV.GTT の直後に屠殺し, 膵組織を採取し組織学的検索を行った。

膵組織の長軸に直角な輪切り切片を，1組織より6 検体作成し，それぞれ 2 検体ずつ，10\%緩衝ホルマリ ン液(LM 用), Bouin 液(免疫組織用), 緩衝 $4 \%$ glutal aldehide(EM 用)にて固定した。それぞれから HE 染 色, PAP 法抗ヒトインスリン抗体染色 (DAKO 社, PAPKIT K512)（以下 PAP 法8)，抽よ゙電影組織標 本を作成し, 脺組織内ラ島細胞, $\beta$ 細胞, さらに insulin 顆粒（以下I顆粒）の動態を観察した。

$\mathrm{HE}$ 染色標本を用いて, 1 個体 2 検体ずつ, 1 標本中 100個のラ島を無作意に抽出し,ラ島を構成する総細胞 数を算出した.

PAP 法染色からも，同様にしてラ島を構成する $\beta$ 細胞数を算出した。

電顕標本は倍率5000で観察し，1検体から30～50枚 の $\beta$ 細胞のキャビネ版プリントを作成した。 Weibel の計量組織学的方法"9)に準じて, Degiplan-200を用い, 1 個体50８0個の $\beta$ 細胞を計測し， $\beta$ 細胞の大ささ, I 顆粒の数と大きさ，I 顆粒がラ島に占める面積の割 合を算出し，I 顆粒の Volume density を求め，各群間 の比率で表示した。

最後に各標本の形態学的観察を行った.

\section{II. 結 果}

1. 膵内分泌機能の評価

1) 術後 3 週時の耐糖能の検討

各イヌについて術後 3 週時に IV. GTTを施行し, 膵切除が耐糖能に扣よ注寸影響をみた（図 2). 膵切除 群および照射群の25頭では血糖の30分, 60分值が高く, 60\%膵切除で軽度の耐糖能低下がみられた。IRIは初 期10分までが正常対照に比べ低值を示し，Peak 值も 低かった。これらを無作意に 3 群に分け以後の実験に 供した。実験群 3 群間には，血糖・IRI 值に全く差はな かった。

2) 耐糖能の経時推移の検討

膵切除または照射が耐糖能に経時的におよぼす影響 を検討した。

切除単独群 (図 3·左) では, 血糖の 2 分値が 3 かカ 
月時でむしろ低いが，以後 60 分まで差はなく 3 週時と 同等であった，IRI 反応は 3 カ月時には低値の傾向で あった。

$30 \mathrm{GY}$ 群（図 3・中）では，3カ月時の血糖が 5 分, 10分で低値を示したが，血糖曲線はむしろ平担であっ た. IRI 反応は 3 週時より低值であった。

$60 \mathrm{GY}$ 群（図3·右）では，3 カ月時の血糖に有意差 はないが，60分での血糖下降の遅れが5かがわれた。 IRI 反応は 3 週時と同等で低值を示した。

小括：膵切除および残存膵照射が耐糖能に経時的に

図 23 週時（照射前）の耐糖能

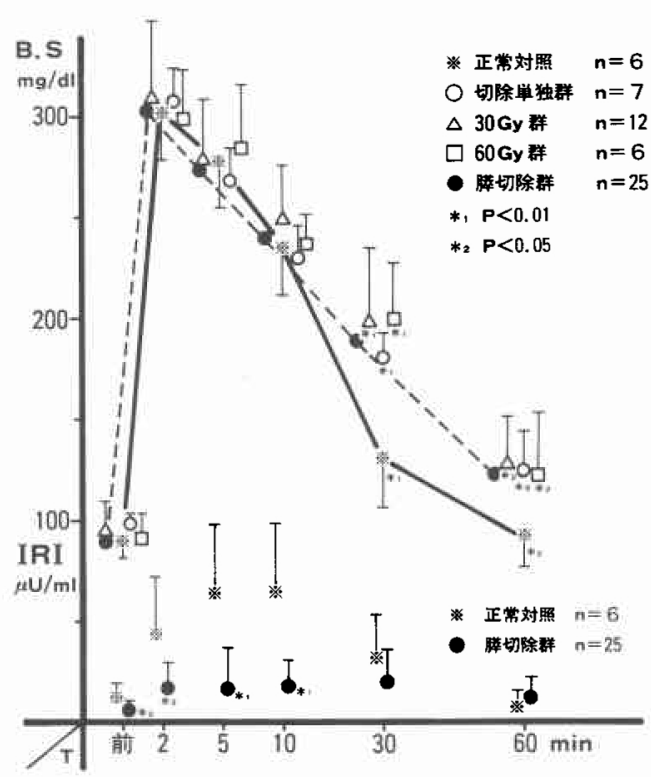

与える影響は 3 カ月時までみられなかった。

3） 3 力月時耐糖能の検討

3 力月時の血糖曲線, IRI 反応を比較し, 照射の有無 および照射量が耐糖能におよぼす影響を検討した（図 4 ・表 1 ).

正常対照との比較では, 初期相 $(2-10$ 分) の血糖 値で有意の高值を示すものはなかった. 後期相 (30 60 分）では実験群がいずれも高値を示し糖消失の遅れを 認めた，IRI 反応は実験群すべてが正常対照に比べ低 反応であった。

3 カ月時実験群間の血梼曲線に差を認めなかった。 IRI 反応は実験群間で有意差を認めたものもあるが一 定の傾向はなく，ほ涪近似して低值であった。

小括：残存膵耐糖能は膵切除により後期相での低下 を認めたが，照射の有無あるいは量による影響はな かった. IRI 反応は正常対照に比べ低值であり，前値と 後期相に有意差があったが，照射による一定の傾向は なかった。

4）I. Iからみた耐糖能の検討

3週時では，正常対照 $0.18 \pm 0.12(\mu \mathrm{u} . \mathrm{dl} / \mathrm{ml} . \mathrm{mg}$ ) に比べ切除単独群 $0.08 \pm 0.08$ (N.S), $30 \mathrm{GY}$ 群0.05土 $0.04(\mathrm{P}<0.05), 60 \mathrm{GY}$ 群0.06士0.06 $(\mathrm{P}<0.1)$ と全 体に低下を示し，有意差がみられた（図 5 )。

3 カ月時では, 切除単独群 $0.06 \pm 0.04,30 \mathrm{GY}$ 群 $0.04 \pm 0.02,60 \mathrm{GY}$ 群0.06士0.01であり, 3 週時より経 時的にやや低下を示したが有意ではなかった。また実 験群間に有意差はなかった。

小括：I. I Kみる耐糖能は $60 \%$ 膵切除により 3 週時 に低下した。 3 カ月時には 3 週時と有意差はなく, 実

図 3 耐糖能の経時推移

切除単独群

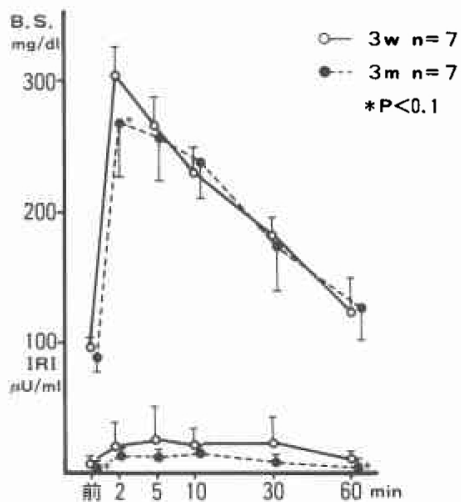

30 Gy 群

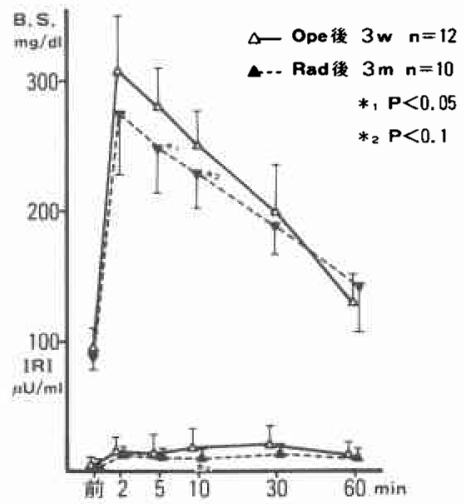

60 Gy 群

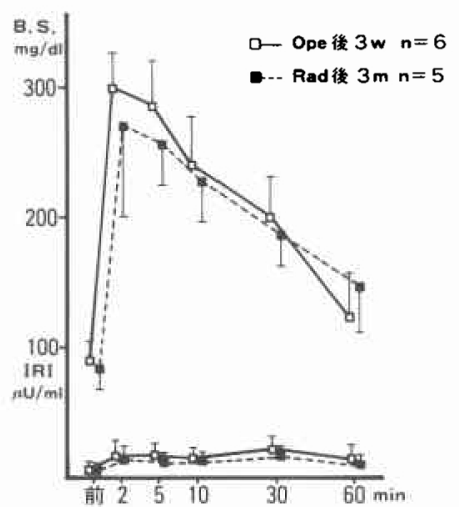


図 43 力月時耐糖能

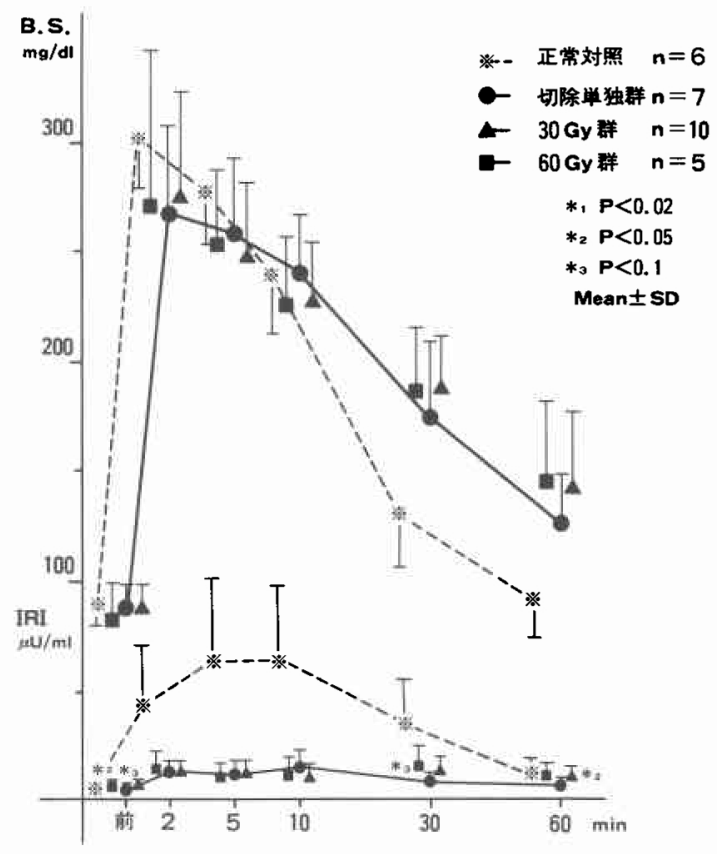

表 13 力月時 IV • GTT の血糖値, IRI 值

\begin{tabular}{|c|c|c|c|c|c|c|c|}
\hline \multicolumn{2}{|c|}{$\Rightarrow \quad$ \$ } & min & 2 分 & 5 分 & 100 & 309 & 604 \\
\hline $\begin{array}{c}\text { 正掌対用 } \\
n=6\end{array}$ & $\begin{array}{l}\text { BS } \\
\text { IfI }\end{array}$ & $\begin{array}{c}89.0 \pm 7.8 \\
\text { 1) n) } \\
\text { 13.2 } 26.4\end{array}$ & $\begin{array}{r}(1) \\
301.7 \pm 22.5 \\
0)(1)=1 \\
42.8 \pm 28.1\end{array}$ & $\begin{array}{r}277.3 \pm 22.8 \\
0)=1 \\
63.0 \pm 36.3\end{array}$ & $\begin{array}{r}235.5 \pm 23.6 \\
\{10) \ldots \\
63.8 \pm 35.1\end{array}$ & $\begin{array}{r}\text { (1) a) (u) } \\
130.3 \pm 24.1 \\
=\text { *) } * 1 \\
33.0 \pm 21.4\end{array}$ & $\begin{array}{r}\text { (1) a) (1) } \\
91.3 \pm 14.1 \\
=2 \\
10.7 \pm 2.8\end{array}$ \\
\hline $\begin{array}{c}\text { 切除学独群 } \\
n=7\end{array}$ & $\begin{array}{l}\text { ES } \\
\text { IRI }\end{array}$ & $\begin{array}{c}8.0 \pm 10.2 \\
\text { 1) }=\text { 本 } \\
4.3 \pm 2.2\end{array}$ & $\begin{array}{r}267.3 \pm 41.2 \\
\text { a) } \\
13.2 \pm 5.1\end{array}$ & $\begin{array}{r}258.1 \pm 35.4 \\
0) \\
13.3 \pm 5.3\end{array}$ & $\begin{array}{c}239.1 \pm 28.9 \\
14 \\
14.8 \pm 8.1\end{array}$ & $\begin{array}{c}174.7 \pm 34.5 \\
\Rightarrow y) \\
9.3 \pm 3.3\end{array}$ & 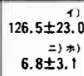 \\
\hline $\begin{array}{l}30 \text { Gy } \begin{array}{l}\text { \# } \\
n=10\end{array}\end{array}$ & $\begin{array}{l}\text { eS } \\
\text { IR! }\end{array}$ & $\begin{array}{r}88.4 \pm 9.6 \\
a)= \\
6.2 \pm 1.7\end{array}$ & $\begin{array}{r}274.1 \pm 47.7 \\
.01 \\
13.4 \pm 4.3\end{array}$ & $\begin{array}{r}\text { 1) } \\
246.4 \pm 33.7 \\
12.8 \pm 4.2\end{array}$ & $\begin{array}{r}227.7 \pm 25.8 \\
.91 \\
11.4 \pm 4.3\end{array}$ & $\begin{array}{c}\text { (0) } \\
188.3 \pm 22.6 \\
\text { *) } \\
13.2 \pm 7.3\end{array}$ & $\begin{array}{r}\text { (14) } \\
142.2 \pm 35.3 \\
* 1.8 \pm 4.7\end{array}$ \\
\hline $\begin{array}{r}60 \text { Gy } \begin{array}{r}z \\
n=5\end{array} \\
\quad\end{array}$ & $\begin{array}{l}\text { BS } \\
\text { IAI }\end{array}$ & $\begin{array}{c}83.0 \pm 14.1 \\
70 * 1.9 \\
7.4 \pm 1.9\end{array}$ & $\begin{array}{c}271.0 \pm 64.4 \\
\Rightarrow \\
14.4 \pm 8.2\end{array}$ & $\begin{array}{r}254.4 \pm 29.4 \\
= \\
11.8 \pm 5.8\end{array}$ & $\begin{array}{r}226.0 \pm 27.5 \\
13 \\
12.2 \pm 7.2\end{array}$ & $\begin{array}{r}187.6 \pm 25.7 \\
\hat{13}) \\
16.4 \pm 7.7\end{array}$ & $\begin{array}{c}146.2 \pm 32.6 \\
11.8 \pm 5.6\end{array}$ \\
\hline \multicolumn{4}{|c|}{ 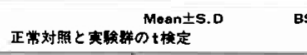 } & $s=m g / d l$ & \multicolumn{2}{|l|}{$I R I=\mu \mathrm{U} / \mathrm{mI}$} & \\
\hline $\begin{array}{l}P<0.01 \\
F<0,102 \\
p<0.06 \\
F<0.1\end{array}$ & & $\begin{array}{l}\text { 1) } \\
\text { a) } \\
\text { को } \\
\text { th }\end{array}$ & a) $x=1$ & $\begin{array}{l}\text { al } n)=1 \\
\text { e) }\end{array}$ & (1) 日) का & 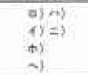 & $\begin{array}{l}\text { A) } a|+4| \\
\Rightarrow ? \\
\Rightarrow ?\end{array}$ \\
\hline
\end{tabular}

験群間でも差はなかった，照射の有無や量による影響 は認めなかった。

5) 血糖消失率 $\mathrm{K}$ 值からみた耐糖能の検討

正常対照 $2.11 \pm 0.24$ 亿対し，3週間時で切除単独群 $1.44 \pm 0.31(\mathrm{p}<0.05), 30 \mathrm{GY}$ 群 $1.46 \pm 0.32(\mathrm{p}<0.01)$, $60 \mathrm{GY}$ 群 $1.5 \pm 0.54(\mathrm{p}<0.02)$ といずれる低下し, 正常 下限あるいは境界型を示した。実験群間に差はなかっ た（図6).

3 力月時では切除単独群 $1.32 \pm 0.33$ (N.S), $30 \mathrm{GY}$

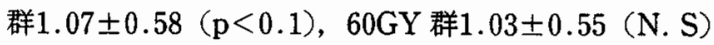

図 5 Insulinogenic Index $(\Delta \mathrm{IRI} / \Delta \mathrm{BS} 2 \mathrm{~min})$

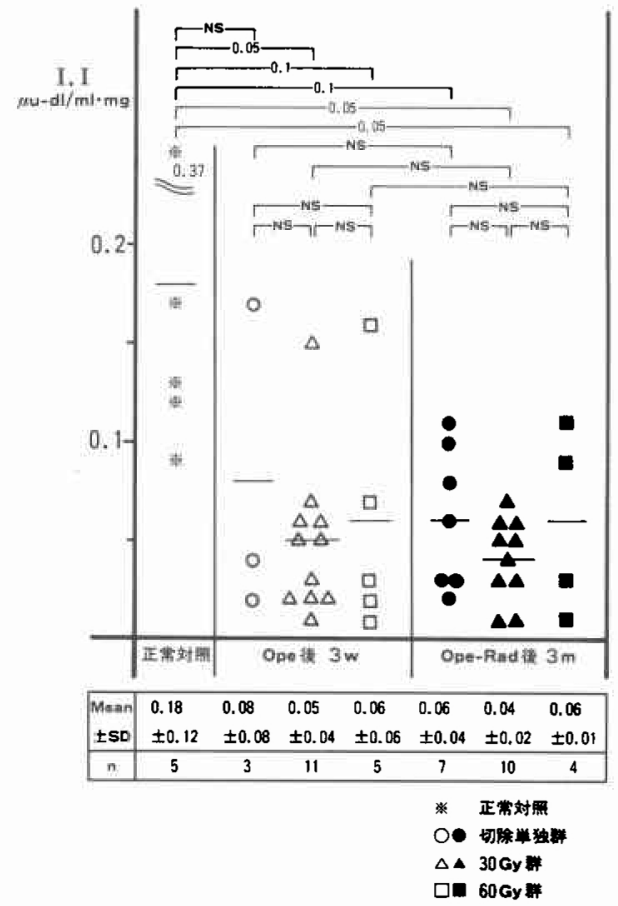

と 3 週時に比べ経時的に低下傾向があるが, 有意の差 はなかった。 また，実験群間では照射群に低い傾向が あるが有意ではなく，照射量による差はなかった。

小括：糖消失率 $\mathrm{K}$ 值の観点からは, 経時的あるいは 照射で $\mathrm{K}$ 値の低下傾向がみられたが, 有意の変化は認 めなかった。

6) IRI Peak 值と Peak Insulin Time の検討

IRI Peak 值は正常対照70.8土16.2 $\mu \mathrm{u} / \mathrm{ml}$ に対し,

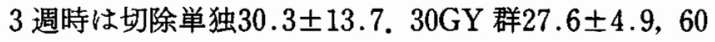
GY 群 $27.0 \pm 5.8$ と60\%膵切除により有意の低下 $(\mathrm{p}<$ 0.01）を示した（図7）。実験群間に差はない。

3 力月時の Peak 値は切除単独群 $21.9 \pm 6.4,30 \mathrm{GY}$

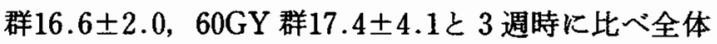
に低下傾向にあったが，有意であったのは30GY 群 （P<0.05）のみであった.

Peak insulin time は正常対照が10.8土4.0分である

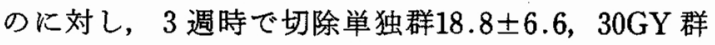
$22.2 \pm 5.2,60 \mathrm{GY}$ 群 $21.5 \pm 9.4$ と膵切除により, $\beta$ 細胞 の反応性の遅れが認められた。

3 カ月時では切除単独群 $10.3 \pm 3.6,30 \mathrm{GY}$ 群 $11.0 \pm$ 4.2 と回復傾向がみられたが, $60 \mathrm{GY}$ 群では $24.8 \pm 10.8$ と遅延したまま（p<0.01）であった。 
図 6 血糖消失率 $\cdot \mathrm{K}$ 値

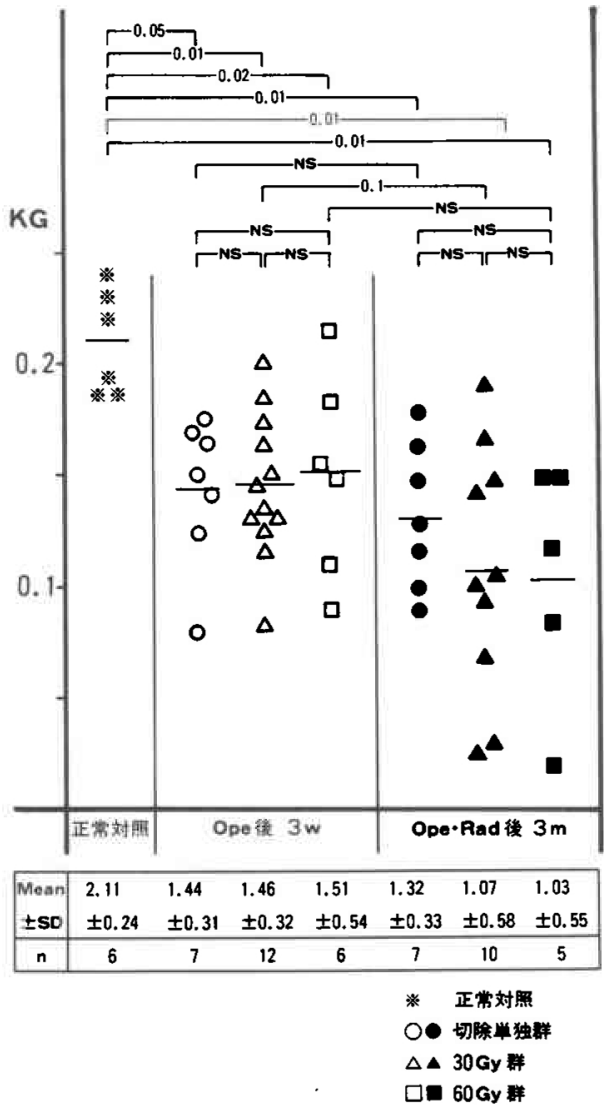

図 7 IRI Peak 值, Peak Insulin Time

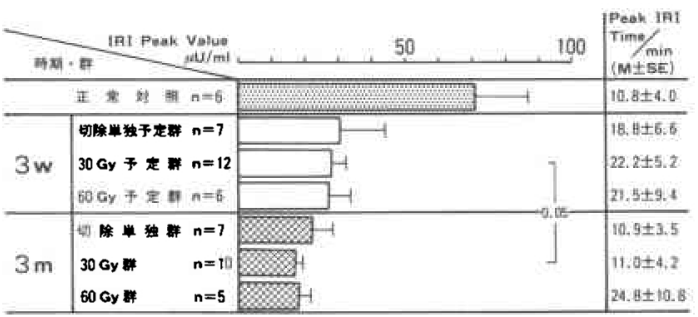

小括；膵切除により低下した IRI peak 値は 3 カ月 時る同等であった. Peak insulin time は60GY 群では 3 力月時にも回復を認めなかった。

7) Insulin 分泌量と T. I. I. の検討

IRI 総分泌量は正常対照 $2155 \pm 511.9 \mu \mathrm{u} . \mathrm{min} / \mathrm{ml}$ に 対 L, 3 週時は切除単独群1209.5土483.4, 30GY 群

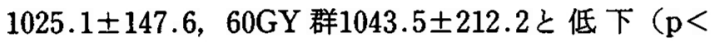
0.01) した（図 8).

IRI 増加量も正常対照1379.3 1382.1 に対し， 3 週時
図 8 Insulin 分泌量と T. I. I.

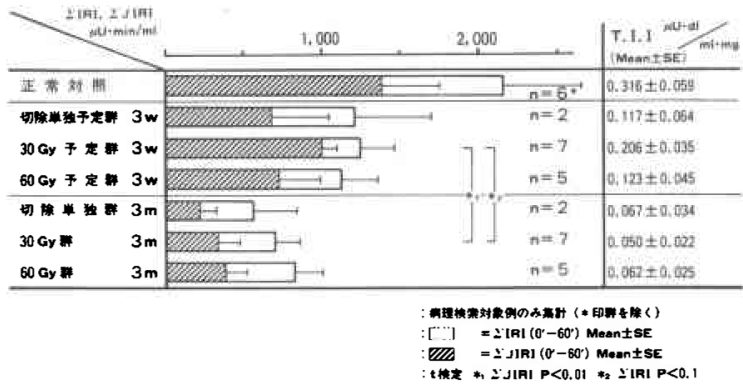

図 9 ラ島内細胞構成

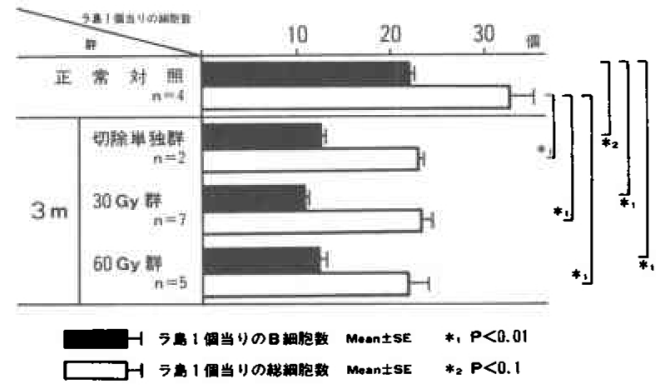

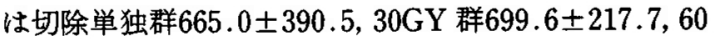
GY 群610.8土249.2 と低下（p<0.01）した。

T. I. I. でも正常対照 $0.32 \pm 0.06 \mu \mathrm{u} . \mathrm{dl} / \mathrm{ml}$. mg に対 ᄂ, 3 週時は切除単独群 $0.12 \pm 0.06,30 \mathrm{GY}$ 群 $0.21 \pm$ $0.04 ， 60 \mathrm{GY}$ 群 $0.12 \pm 0.05$ 之耐糖能の低下 $(\mathrm{p}<0.01)$ が認められた。

3 力月時の検索ではIRI 総分泌量は切除単独群

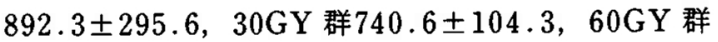
830.4土181.7であり，3 週時と比べ低下傾向にあるが 有意差はなく，実験群間にも差はなかった。

IRI 増加量では 3 力月時は切除単独603.9土244.0,

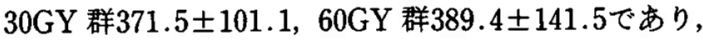
3 週時と比べ30GY 群で低下 $(p<0.1)$ が認められた。 実験群間に有意差はなかった。

T. I. I. は 3 力月時切除単独群 $0.07 \pm 0.03,30 \mathrm{GY}$ 群 $0.06 \pm 0.02,60 \mathrm{GY}$ 群0.06士0.03で, 3 週時と比べ低下 傾向はあるが有意差はなく, 実験群間にも有意差はな かった。

小括；IRI の分泌反応は60\%膵切除により低下し, 30GY 群に分泌量の経時的な低下を認めた。しかし 3 カ月時の実験群間では, 照射の有無や量による違いを 認めなかった。 
2. 計量組織学的検索によるラ島 $\beta$ 細胞機能の評価

1） ラ島内細胞構成の検討

正常対照で $32.8 \pm 3.8$ 個あったラ島内総細胞数は, 切 除単独群23.1 $\pm 5.4(\mathrm{p}<0.01), 30 \mathrm{GY}$ 群 $23.3 \pm 3.1$ ( $\mathrm{p}<$

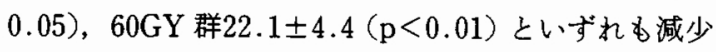
した(図 9). 実験群間に有意差はなく, 照射の有無や 量による影響は認めなかった。

正常対照で22.1士1.5個あったラ島内 $\beta$ 細胞数は, 切除単独群 $12.5 \pm 1.6,30 \mathrm{GY}$ 群10.8土1.5, 60GY 群 $12.3 \pm 2.1$ と実験群で減少（ $\mathrm{p}<0.01 ） し た 。$ 実験群間 には有意差はなく，照射の有無や量による影響は認め なかった。

総細胞数に占める $\beta$ 細胞の割合は正常対照, $67.4 \%$ であるのに対し, 切除単独群 $54.3 \%, 30 \mathrm{GY}$ 群 $46.2 \%$, 60GY 群55.6\%であり，実験群で低い傾向にあった。照 射による一定の傾向はなかった。

小括：膵切除によってラ島内総細胞数, $\beta$ 細胞数の 减少がみられたが, 照射による影響はみられなかった。

2) 電顕観察に基づく $\beta$ 細胞機能の検討

観察が可能であった電䫒標本について各群 2 検体よ り，それぞれ50８0個のラ島を観察し計量組織検討を 行った（表 2).

$\beta$ 細胞の大きさは正常対照 5075 に対し, 切除単独群 は6422 と大きく, 30GY 群3566, 60GY 群4182 と照射群 では小さい傾向にあった。

I 顆粒の大きさは正常対照11.3に対し, 切除単独群
17.3,30GY 群19.8,60GY 群15.1と実験群で大きかっ た. 照射の有無や量による一定の傾向はなかった。

$\beta$ 細胞 1 個当りのI 顆粒の個数は正常対照 47.5 に対 し, 切除単独群 $52.4,30 \mathrm{GY}$ 群 $48.3,60 \mathrm{GY}$ 群62.1 同等か増加の傾向にあった。

$\beta$ 細胞単位面積当りのI 顆粒の個数は正常対照 9.4 に対し, 切除単独群 $8.2,30 \mathrm{GY}$ 群 $13.5,60 \mathrm{GY}$ 群 14.9 と，照射群で増加していた。

各 $\beta$ 細胞での I 顆粒の動向の指標として, $\beta$ 細胞中 にI 顆粒が占める割合 volume density (以下 V. D) を求めたところ正常対照10.6に対し, 切除単独群14.1, $30 \mathrm{GY}$ 群26.9, 60GY 群22.4と実験群で増加の傾向に あった。

小括：電顕像の計量組織学的検討から，I 顆粒の増 加と V. D の増加がみられ, 実験群ラ島内 $\beta$ 細胞での I 顆粒産生立進が示唆された。

\section{表 2 電顕像の計量組織学的検討}

\begin{tabular}{|c|c|c|c|c|c|}
\hline & $\begin{array}{l}\text { B.coll } \\
大 \text { 大 है }\end{array}$ & $\begin{array}{l}\text { Insulin } \\
\text { 帮の大 }\end{array}$ & $\begin{array}{l}\text { B-call 糔の } \\
\text { I }\end{array}$ & 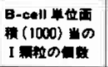 & $\begin{array}{l}1 \text { mand } \\
\text { Volume } \\
\text { Density }\end{array}$ \\
\hline II 奶 需 & 5075 & 11.3 & 47.5 & 9.4 & 10.6 \\
\hline 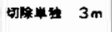 & 6422 & 17.3 & 52.4 & 8.2 & 14.1 \\
\hline $30 \mathrm{~Gy} \quad 3 \mathrm{~m}$ & 3566 & 19.8 & 48.3 & 13.5 & 26.9 \\
\hline $60 \mathrm{~Gy} \quad 3 \mathrm{~m}$ & 4182 & 15.1 & 62.1 & 14.9 & 22.4 \\
\hline
\end{tabular}

図10 H-E 染色像

切除単独群

軽度線維化あり

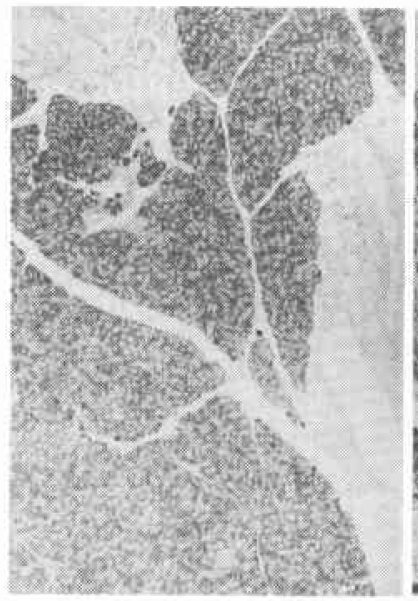

$30 \mathrm{~Gy}$ 群

線維化やや強い
$60 \mathrm{~Gy}$ 群

間質の線維化あるが

腺房構造は保たれている
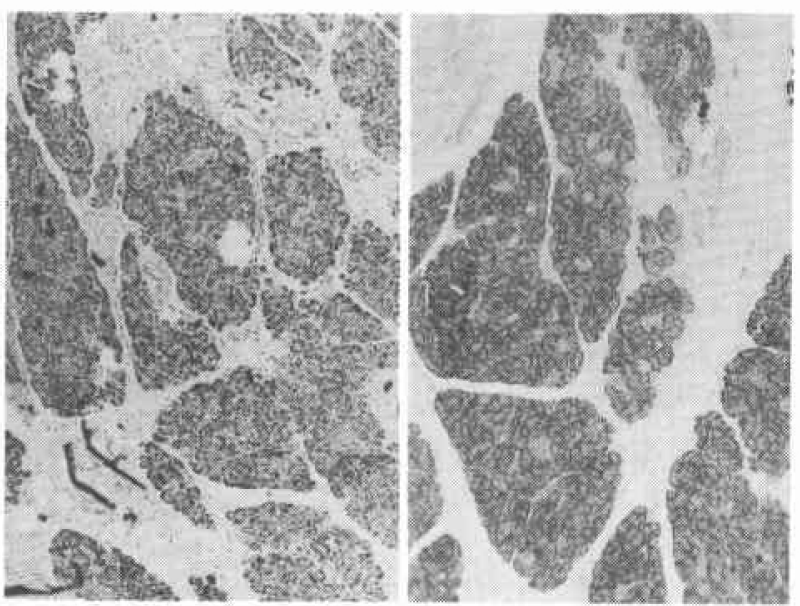

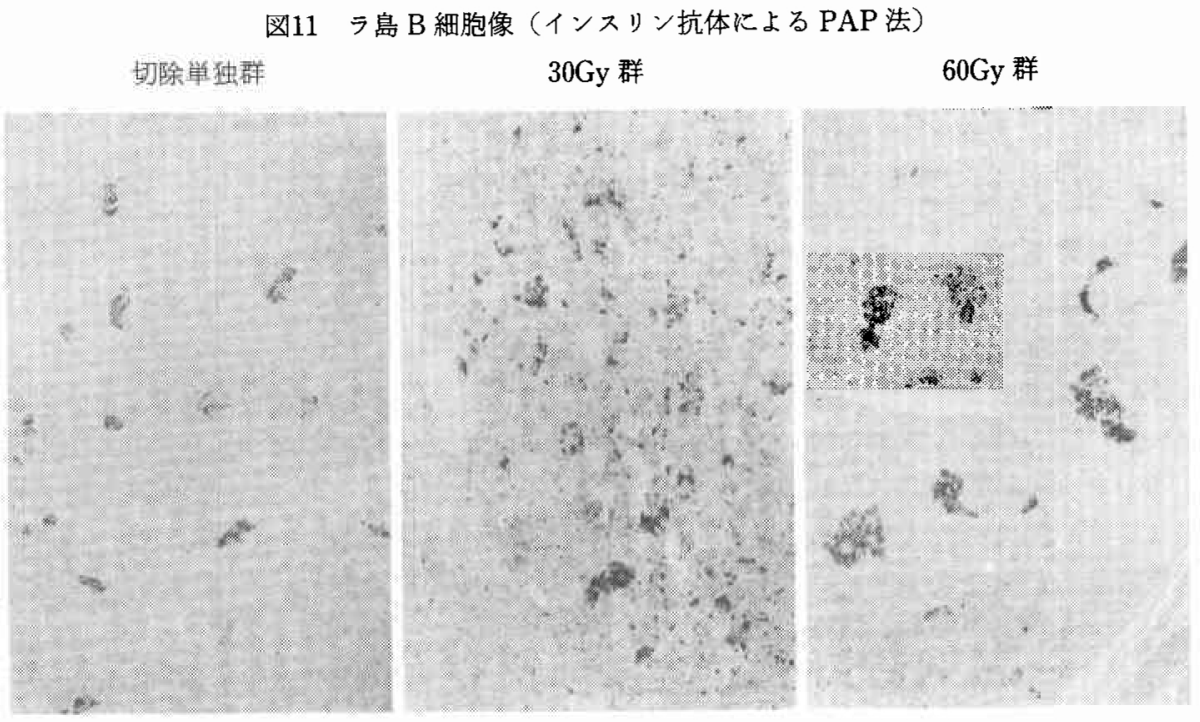

図12 電䫓組織像 $(\times 5000)$

切除単独群

５氏島細胞と外分泌細胞 は比較的厚い基底膜により 境され，B-cell はやや数を 减じ不完全な D 細胞顕粒 を有する細胞やいずれの細 胞とも判別不能な細胞も乙 ばしぱみられる。

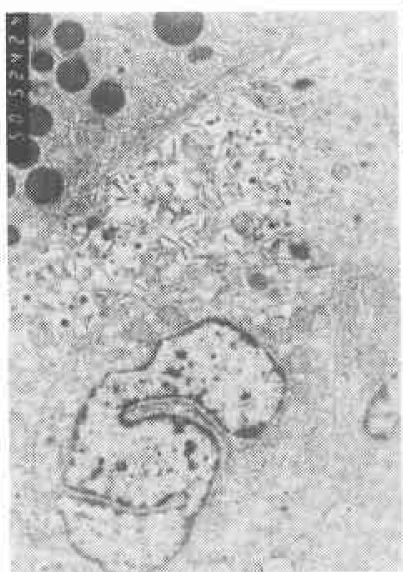

$$
\text { 30Gy 群 }
$$

B-cell 内 $の$ Inslin 顆粒 の数は増加している印象を 与ええる. B-cell の外周は しばしば比較的厚い基底膜 により扮扮われ血管周囲に は厚い膠原線維がとりまい ている。

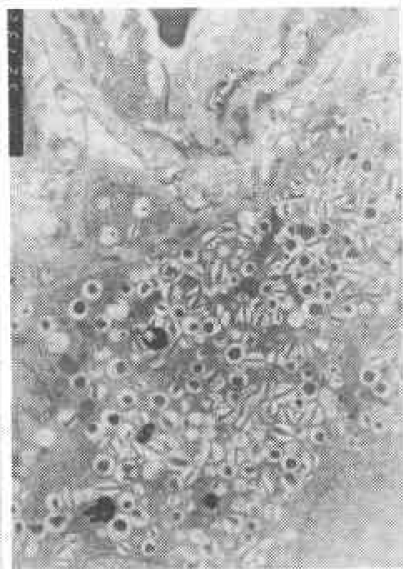

60Gy 群

B-cell 内のインスリン顆 粒はしばしば腫大し，時と して内腔に構造物を認めな いこともある.ゴルジ装置 の発達はよい.

\section{3. 形態組織学的観察}

1) $\mathrm{HE}$ 染色光顕像の検討

切除単独群では膵管周囲の線維化があるが，実質細 胞の変化はなかった. $30 \mathrm{GY}$ 群は小葉間の線維化が進 んでいるが, やはり実質細胞の変化はなかった。 60GY 群は小葉間の線維化が進さが，小葉構造は保たれてい
た（図10）.

2) PAP 法光顕像の検討

切除単独群では均等なラ島が散在していた。 $30 \mathrm{GY}$ 群はラ島の大小不同があり，一部密集していた。 60GY 群でもラ島の大小不同があるが，ラ島形態は保たれて いた。、いずれも染色性は良好だった（図11）。 
3) 電顕像 $\times 5,000$ 検討

切除単独群では正常と比べI 顆粒の増加をみた。 $\beta$ 細胞は比較的厚い基底膜に覆われていた，30GY 群は I 顆粒の変形がみられ, 数はやや減じ, 基底膜も厚い. $60 \mathrm{GY}$ 群は I 顆粒の肥大・空胞化を認め基底膜はやや 厚いが、ゴルジ装置の発達はよかった（図12）。

\section{III. 考 察}

膵に対する放射線照射の影響に関しては，1920年代 からイヌを用いた幾つかの実験報告10) 14)があり，膵の 線維化, ラ島細胞の変化, 外分泌機能の推移について 報告されている.内分泌機能に関しては尿糖，血糖， 近年ではIV. GTTを用いて検討され・照射後も膵内 分泌機能は温存されるとするものがほとんどである. しかし, IRI 分泌を加味した定量的な解析の報告はみ られなかった。そこで著者は本実験で，臨床をふまえ た体外分割照射として腺癌の治瘾線量45 50GYを基 準 ${ }^{15)}$ に, 臨床効果30GY 相当执よび60GY 相当を照射 し, 内分泌機能の定量的解析とラ島機能の検討を試み た.

3 力月時の耐糖能では, 血糖曲線は正常対照に比べ 後期での軽度上昇をみた。諸家の報告の中で Fisher ${ }^{10)}$ は, 4 5 human erythema doses (以下 E. D.) の一 回照射で脺構造が失なわれたと述べている，4５ E. D. は18 22.5GY 相当であり, 著者の 60GY 群は36GY が実地照射量である。照射の効果は照射量や照射方法 で異なる ${ }^{3)}$. Archambeau ${ }^{12)}$, Pieroni ${ }^{16)}$ は体外分割照射 を行い, 膵線維化は認めたがラ島や $\beta$ 細胞は温存さ れ，血糖值は正常であったと述べている，一方， $\mathrm{Volk}^{13)}$, Wellmann ${ }^{14)}$ による照射後の膵の経時的な電 顕観察では, 1 回大量照射 (50 90GY) で組織变化は 2 時間後から始まり，4 日目から 3 週にかけI 顆粒の 変性が進み, その異常は $3 \sim 4$ 力月続くが 8 9 月 で正常化するとしている，分割照射は 1 回照射量が少 ないことで影響が小さくなると推測されるが，照射の 影響をみる上ではさらに長期の観察も必要である。

耐糖能を定量的に評価するために行った $\mathrm{K}$ 值の検 討では, 膵切除により 3 週時で 1.5 前後に低下し，3 3 力 月時は有意差はないが 1.2 前後の境界型となった。耐糖 能を血糖と IRI の相関で定量的に求めた I. I. では 3 週 時から低値を示した。この值はヒトの臨床成績で糖尿 病レベルとなり，血糖曲線や $\mathrm{K}$ 値と合致しない。これ ら耐糖能の指標の成績を検討する上で, IRI 分泌や $\beta$ 細胞機能の動態を明らかにする必要がある。

3 カ月時での IRI 反応は, 実験各群ともに著明に低
下しており，特に10分までの初期反応で顕著である. 五島 ${ }^{17}$ は Sandmeyer 型糖尿病発生に関するイ又の膵 切除量の実験で, $70 \sim 88 \%$ 膵切除後 $3 \sim 10$ 週の非糖尿 病期の IV. GTT で同様所見を報告している.五島は この正常反応の第 1 相 (=Grodsky ${ }^{18)}$ の stored insulin）の欠如は，膵切除によりもたらされ，引きつづき 分泌されるIRIにより耐糖能が維持されるとしてい る.著者の実験成績も五島の反応とよく一致しており， IRI 反応の低下は照射による差がないことからも膵切 除によると考えられる.

この IRI 反応の特徵を検討したところ, IRI の Peak 值は 3 カ月時にも低下していたが, peak insulin time は, 3 力月時は切除単独群, $30 \mathrm{GY}$ 群で回復していた。 もちろん反応時間のみでは，ラ島が照射の影響から回 復したとは断定できない。

そこで量的な反応性を分泌量から，また分泌された IRI の機能性を T. I. I. で検討した。 3 カ月時の IRI 総 分泌量と増加量は実験群で差がなく，照射の影響はな い.一方それらの IRIが十分機能しているかについて は，実験成績での対照となる報告がない，ヒトと単純 に比較はできないが，米村 ${ }^{199}$ の臨床例との比較では, $50 \%$ 膵切除後 2 年以降の T. I. I. $0.065 \pm 0.015$ に該当 した. $65 \%$ 膵切除後 2 年以降で T. I. I. は0 $024 \pm 0.010$ となり, 胃切を加えた際の長期予後で Sandmyer 型糖 尿病発生の危険性を指摘している。本実験の値では粐 尿病は発生しておらず，これらの IRI 分泌量で耐糖能 が維持されると考兄られる。 しかし 3 週時と 3 力月時 とでは，分泌量・増加量は経時的に低下して打り，こ の IRI 分泌の経時的低下をもたらす何らかの機序を検 討する必要がある.HE 染色および PAP 染色により計 測したラ島内細胞数の検討では, 膵切除により総細胞 数・ $\beta$ 細胞数が減少しているが，照射による影響はな い. 数の減少はあるが PAP 法染色でみる限りラ島形 態は保たれており，照射が $\beta$ 細胞を直接障害破壊して 減少したとは考完難い.PAP法による染色性子良好 で，ラ島機能を有していると類推できる。

電顕標本での $\beta$ 細胞の計量組織学的検索で, 正常対 照と比べ実験群では, (1) $\beta$ 細胞は切除単独群で大き く, 照射群では小さくなる. (2) I 顆粒は実験群で大き くなる, (3) $\beta$ 細胞 1 個当りの I 顆粒の個数は, 同等ま たは増加する, (4) $\beta$ 細胞単位面積当りのI 顆粒の個数 が照射群で増加する, (5) $\beta$ 細胞に対するI 顆粒の vlume density が増加することが判った。このことか ら I 顆粒の産生増加 $=\beta$ 細胞機能の六進が推測され 
た.

林 ${ }^{200}$ は膵癌の糖尿病症例を検討し, ラ島教. I 顆粒の 増加とラ島の委縮傾向をみている. 石館 ${ }^{21)}$ と卜膵癌 の検索で，糖尿病合併症例ではラ島の小型のものが多 く, 大小不同例が多いとしている. 五島 ${ }^{17} は$ Sandmeyer 型糖尿病犬において, 糖尿病初期では $\beta$ 細胞の 分泌顆粓の減少々脱顆粒を認め, $\beta$ 細胞の原形質の淡 明化や萎縮変性とともに機能的な IRI 分泌能低下の所 見としている.一方照射後の電顕所見としてVolk ${ }^{13)}$ Wellmann ${ }^{14)}$ は, $\beta$ 細胞の縮小と I 顆粒の変性, 顆粒の 形の異常を指摘しているが， $8 \sim 9$ カ月で回復してお り血糖值の異常もみていない. Tersigni' ${ }^{22}$ る ヌの膵 に 1 回大量照射後, $\beta$ 細胞の中等度の脱顆粒をみてい るが，20〜25日で障害の緩和がみられ，耐糖能が保た れていることからす B 細胞は温存されるとしている。 本実験に打ける照射群のラ島の委縮や I 顆粒の増加 が，耐糖能の低下に基づくものか，照射の影響による 回復可能な変化であるのかは判定し党ない。しかしこ れらの I 顆粒が先に示したレベルで血中に移行し，血 糖曲線にみた耐糖能を維持していることは明らかであ る。若干の耐糖能低下はあるが，ラ島機能がえ進する ことで維持されていると推測された。

光顕像による膵の形態学的観察では, 照射群で線維 化がやや進んでいる．林 ${ }^{211}$ は膵癌糖尿病症例の IRI の 低反応と遅延の一因に，ラ島周辺の線維化による IRI の血中移行の障害を挙げている. 桑原 ${ }^{23)}$ る膵癌・慢性脺 炎症例の門脈血中 IRI 濃度の測定から, 膵線維化によ る IRI の門脈血中移行の低下が内分泌機能低下をもた らすとしている.しかし, 著者の実験群の線維化は比 較的軽度であった。本実験の線維化の程度を, 木林 ${ }^{24)}$ 慢性膵炎に関する組織学的研究での光顕像による分類 にあてはめると, grade II から grade III の初期に属す る. 木林の電顕像では $\beta$ 細胞の空胞形成や I 顆粒の減 少, 粗面小胞体の不規則な拡張像をみている.grade III で膵島は周囲の線維化により影響をうけるが，ラ島細 胞は正常な構造を有し，内分泌顆粒も十分有するため 機能上ほとんど問題ないと推測している。この観察所 見は本実験の内分泌能とも合致しており, 形態学的面 からも納得のいくものである.

電顕像の形態組織学的観察で, $\beta$ 細胞の基底膜の肥 厚と血管周囲の膠原線維の増生が観察された。一方 60 GY 群でもゴルジ体はよく保存されていた，IRIは粗 面小胞体一ジルジ系で形成されるが25)，その形成の場 で障害をうける可能性もある。I 顆粒の変形はそれを
示している可能性もあるが，ゴルジ体が保存されてい ることから生成機能は保持されていると考光る。ささら にI 顆粒が放出される過程に関して開口分泌方式 ${ }^{25) な ~}$ どがいわれている。電顕像にみられた基底膜の肥厚が I 顆粒分泌の障害となる可能性も考兄られる.このこ とが 3 週時から 3 力月時にかけての IRI 分泌量の低下 と関係している可能性もある.さらに, IRI は分泌後ラ 島周辺から外分泌細胞へ向から膵島一腺房門脈系によ り運ばれる。 その微細血管構築 ${ }^{26) 27}$ とラ島の間に生じ る光顕像での線維化や電顕像の血管周囲の膠原線維の 増生が血中移行に影響を与兄る可能性もある. 先の桑 原 ${ }^{23)}$ の門脈血中 IRI 濃度の低下所見もこの機序と所見 を考えると納得できる。

これらの組織変化については切除あるいは照射の 個々の因子に分けての解析はできなかった。米村199 は 膵大量切除後は $\beta$ 細胞の变性を促進する状態にあり, overfunctionにより $\beta$ 細胞の減少をきたし, Sadmeyer 型糖尿病に移行すると述べている. 五島 ${ }^{17)}$ 女膵 大量切除で機能的な IRI 反応の低下, 抗 IRI 系機能の 元進を認め $\beta$ 細胞の退行变性が進むとした。一方照射 の影響に関して, Wellmann ${ }^{14)}$ のごとく8〜9カ月後 に組織所見が正常に回復するとした報告むある。これ らを明らかにするには各因子を区別した長期の観察結 果をまたなければならない. しかし少くとも, イヌを 用いての $60 \%$ 膵切除・残存膵照射 3 力月時において, 耐糖能低下は軽微であり, IRI は機能え進を呈するラ 島 $\beta$ 細胞で産生されており, 境界型を維持するレベル の血中分泌も, 切除単独群と同時に保持されている事 実が観察された。

\section{結語}

膵部分切除後の残存膵に対する体外分割照射が，耐 糖能に与える影響を知る目的で，雑種成犬を用い $60 \%$ 膵切除後, 臨床効果 $30 \mathrm{GY}$ 相当拉よび $60 \mathrm{GY}$ 相当の照 射を行い, 3 力月後に種々の内分泌機能検查々組織学 的観察を行い, 以下の結論を得た。

1） $60 \%$ 膵切除により耐糖能は, 糖尿病境界型に低下 したが，照射の有無の影響は，血糖曲線，I. I. , 糖消 失率 $\mathrm{K}$ 值で認めなかった。 また, 30GY と60GY の照射 量の違いによる影響を認めなかった。

2）残存膵の IRI 反応は膵切除により低下したが, IRI 総分泌量・増加量は, 照射の有無や量による影響を 認めなかった。 IRI の peak time の回復が60GY 群で 遅れていた。

3）ラ島内総細胞数, $\beta$ 細胞数は膵切除後減少した 
が，照射の有無や量による影響を認めなかった。

4）電䫓組織の計量組織学的検討により，I 顆粒およ びI 顆粒の volume density の増加がみられ, $\beta$ 細胞機 能の亢進が示唆された。

5）以上の事実から, $60 \%$ 膵切除後の残存膵に対する 30GY, 60GY の体外分割照射は, 3 力月時の耐糖能に 影響を与えず, また境界型を示した耐糖能は, $\beta$ 細胞機 能の亢進により維持されるものと考兄られた。

稿を終るに臨み, 御指導·御校閲を賜った恩師田辺達三教 授に深謝の意を捧げます。また終始御助言御協力くださっ た加藤紘之講師, 阿部一九夫助手, 本学放射線学教室过 博 彦助教授, 札幌医科大学第 2 病理学教室吉田豊講師, ならび に第 2 外科学教室員諸兄に, 感謝の意を表します.

なお本論文要旨は, 第 84 日本外科学会総会, 第 85 回日本外 科学会総会で発表した。

\section{文 献}

1) Miller TR, Fuller LM: Radiation therapy of carcinoma of the pancreas. Am J Roentgenol $80: 787-792,1958$

2) 小高通夫, 竜 崇正, 碓井貞二ほか：消化器癌に対 する放射線療法 (肝・胆・膵)。日外会誌 $85: 1067$ $-1071,1984$

3) Orton CG, Ellis $S$ : A simplification in the use of the NSD concept in practical radiotherapy. Br J Radiol $46: 529-537,1973$

4) Seltzer HS, Smith WL, Dallas MS: Plasma insulin activity after glucose. Diabetes $8: 417$ $-424,1959$

5) Lundbaek $\mathrm{K}$ : The intravenous glucose tolerance test. Triangle $6: 194-198,1964$

6) Miyata M, Takao T, Okamoto E: An appraisal of pancreatoduodenectomy based on insulin secretion. Am J Surg 133 : 577-581, 1977

7) Seltzer HS, Alle EW, Horron AL: Insulin secretion in responce to glycemic stimulus. $\mathrm{J}$ Clin Invest $46: 323-335,1967$

8) Sternberger LA, Hardy PH, Curulis JJ et al : The unlabeled antibody enzyme method of the immunohistochemistry. J Histochem Cytochem $18: 315-333,1970$

9) Weibel ER, Kistler GS, Scherle WF : Practical sterological methods for morphometric cytol. ogy. J Cell Biol 30:23-38, 1966

10) Fisher NF, Groot JT, Bachem A: The effect of X-ray on the pancreas. A, J Pathol 76:299 $-305,1926$

11) Orndoff BH, Farrell JI, Ivy AC: Studies on effect of roentgen rays on glandular activity. Am J Roentgenol 16:349-354, 1926
12) Archambeau J, Griem M, Harper P: The effect of $250 \cdot \mathrm{KV}$ X-ray on the dogs. Radiation Res 28:243-256, 1966

13) Volk BW, Wellmann KF, Lewitan A: The effect of irradiation on the fine structure and enzymes of the dog pancreas. Am J Pathol 48 : 721-753, 1966

14) Wellman KF, Volk BW, Lewitan A: The effect of radiation on the fine structure and enzyme content of the dog pancreas. Lab Invest $15: 1007-1023,1966$

15) Fletcher $\mathrm{GH}$ : Clinical dose $r$ esponse curves of human malignant epitherial tumores. $\mathrm{Br} \mathrm{J}$ Roentgenol 46:1-12, 1973

16) Pieroni PL, Rudick J, Adler M et al: Effect of irradiation on the canine exocrine pancreas. Ann Surg 184:610-614, 1976

17) 五島博道: 膵切除後糖尿病の病態生理の研究. 特 に Sandmeyer 型糖尿病における糖代謝ならびに 膵島の変化について。 日外会誌 $80: 542-551$, 1979

18) Grodsky GM, Landahl H, Curry $\mathrm{H}$ et al: In vitro studies suggesting a two compartmental model for insulin secretion. Eited by Falker $\mathrm{S}$ The structure and metabolism of the pancreatic islets. Pergamon Press, Oxford, 409-421, 1970

19）米村豊：膵切除量と膵内分泌。十全医会誌 $88: 307-337,1979$

20）林訑欽, 森 洋, 織部孝史结品: 膵癌症例飞未。 ける綟尿病との関連性について。 日消外会誌 $15: 1758-1764,1982$

21）石舘卓三：原発性膵癌の病理組織学的研究. 第 2 編. 原発性膵癌々併発性梼尿病との関係。秋田医誌 $4: 18-28,1967$

22) Tersigni R, Toredo-Pereyra LH, Parestini $M$ et al: Effect of ex vivo hypothermic irradiation on duct ligated pancreas allografts in dogs. Am Surg $46: 713-721,1980$

23）桑原義明：膵癌と慢性膆资における膵内分泌機能 障害の発生機序について. 日外会誌 $86: 73-83$, 1985

24）木林速雄：慢性萃资に拁ける膵島細胞の組織化学 的, 電子顕微鏡的研究. 岡山医誌 $87 ： 497-527$, 1975

25）渡 仲三: 膵内分泌細胞の電子顕徽鏡的観察. 日 臨 $31: 490-504,1973$

26）柳沼信久, 高橋 徹, 斉藤 謙ほか: 人愺葴の構築 原則に関する研究. 日消病会誌 $78: 1282-1291$, 1981

27）永田和之：膵葴の微小血管構筑および循環動態に 関する研究 (その1) -とくに膵内外分泌の相関に ついて。慈恵医大誌 $96: 673-686,1981$ 